\title{
Public Spending and Growth in the Countries of the Economic Community of West African States
}

\author{
Amath Ndiaye \\ FASEG University C. A. DIOP DAKAR, Dakar, Senegal \\ Email: amathndiay@gmail.com
}

How to cite this paper: Ndiaye, A. (2018) Public Spending and Growth in the Countries of the Economic Community of West African States. Modern Economy, 9, 19491975.

https://doi.org/10.4236/me.2018.911122

Received: July 5, 2018

Accepted: November 26, 2018

Published: November 29, 2018

Copyright $\odot 2018$ by author and Scientific Research Publishing Inc. This work is licensed under the Creative Commons Attribution International License (CC BY 4.0)

http://creativecommons.org/licenses/by/4.0/

\begin{abstract}
Our research focuses on the impact of government spending on economic growth in the countries of the Economic Community of West African States (ECOWAS). It draws on new theories of endogenous growth, and more specifically on Rajhi model. After the tests of specification, an ARDL model was estimated for each of the countries which have cointegration relationships. For those whose cointegration relationship does not exist, a VAR estimate was made. So according to estimates, Total Public Spending in most of the countries of ECOWAS has not positive influence on the economic growth as well in the short term as in the long term. Also in most of the countries, Public Consumption did not positively affect economic growth as well in the long run as in the short run. Regarding Public Investment, we have the same results; it does not positively affects economic growth in most of the ECOWAS countries. Burkina Faso, Guinea and Ivory Coast are the three excepted countries where Total Public Spending has a positive effect on GDP growth in the long term but not in the short run. For further analysis we looked at Public Consumption and Public Investment. It is only in four out of ten countries of the sample that, we found that Public Consumption expenditures positively affect economic growth in the short term while the impact generally is negative in the long term. Regarding Public investment, it is only in three out of ten countries (Burkina Faso, Côte d'Ivoire, Ghana), that it was found determinant to economic growth in the long term.
\end{abstract}

\section{Keywords}

Economic Growth, Public Spending, ECOWAS

\section{Introduction}

The role of government spending in recent models of endogenous growth is 
reconsidered with vigor, especially with the work of Barro [1]. The latter, assuming the existence of a single sector and constant returns to scale, developed a model where public spending play a driving role in the expansion of the gross domestic product. In this model, he assumes that government expenditures are included in the production function [1]. By incorporating public spending in the traditional production function, he considered that this factor has positive externalities, by inducing positive effects on factorial returns. These models of Barro come to explain the differential of growth and development between countries by the differential of marginal effectiveness of public spending. They also highlight the fact that this is not the level of spending or it share in gross domestic product that accounts for the economic growth, but their marginal effectiveness. So, the factors related to the structure, the quality and the use of expenditures are crucial to explain economic growth.

Later, other works [2] [3] [4] analyzed the role played by public spending (in health, infrastructure and education) in economic growth. Indeed, for Tanzi and Zee, public spending can affect the rate of economic growth by at least two channels. First, they exercise a direct influence by increasing the stock of capital in the economy through, for example, public investment in infrastructure (which can be complementary to private investment) or investment of state owned enterprises. Second, government spending indirectly influences the economic growth by increasing the marginal productivity of the factors of production, through spending on education, health and other services that contribute to the accumulation of the human capital.

Moreover, the effect of government spending on economic growth is still an unresolved issue theoretically as well as empirically. Although the theoretical positions on the subject are quite diverse, the conventional wisdom is that a large government spending is a source of economic instability or stagnation. Empirical research, however, does not conclusively support the conventional wisdom. A few studies report positive and significant relation between government spending and economic growth while several others find significantly negative or no relation between an increase in government spending and growth in real output. Few studies have been done for Sub Saharan African countries; so this one is a contribution to fill the gap.

The main objective of our paper is to look at the effectiveness of public spending in the ECOWAS countries. Indeed, these countries that plan to create a single common currency must strive to implement effective budgetary policies insofar as they will have lost their individual monetary sovereignty. This study is a contribution to the debate on the conditions for the creation of a single currency in ECOWAS. Indeed, we consider that if ECOWAS countries want to create a monetary zone, they must not only converge on fiscal policies, but also make the fiscal policies effective on economic growth

The effectiveness of public spending is measured here by the positive impact on the GDP growth. Thus, through an endogenous growth model that takes into 
account some of the control variables, we will see if public expenditure variables have a positive or negative impact on GDP.

We also have two specific objectives that are: looking at the impact of public investment on economic growth and at the effect of public consumption on growth.

So, the article is organized as follows: The first part is a review of the empirical literature on the relationship between public spending and economic growth. The second step sets out the methodology of the study. Finally the third part presents the econometric results and their analysis.

\section{Review of the Empirical Literature on the Impact of Government Spending on Economic Growth}

From an empirical point of view, several authors have highlighted the link between public spending and economic growth both in developed countries and in developing countries.

In an empirical study on 98 countries to appreciate his endogenous growth model augmented by public expenditures, Barro [1] showed that the effect of government spending on economic growth is negative. Indeed, the author found that components of public spending such as education spending, health expenditures, and those assigned to the security do not significantly affect economic growth. Devarajan et al. [5] from the data from 43 countries with for model OLS concluded that public spending has a positive and significant effect on economic growth, but that the relationship between the components of public expenditures and capital growth is negative. According to these authors, the productive spending when they are used in excess can become unproductive, reflecting a misallocation of public spending on capital expenditures.

Dia [6] found that the increase in public spending led economic growth in Senegal when these expenses are intended to finance investment rather than consumption. Similarly, Taiwo and Abayomi [7], found the existence of a positive relationship between public expenditure and GDP. On the other hand, the works of Ojo and Oshikoya [8] and Tenouk [9] found a negative relationship between public expenditure and GDP per head in the countries of West African Economic and Monetary Union (WAEMU). Also Nubukpo [10] found, in the short term, a negative relationship between public expenditure and GDP in most of the countries of WAEMU.

Keho [11], in a VAR model concluded that total public spending, education spending and capital expenditures have no significant impact on the gross domestic product (GDP), but the evolution of the GDP growth has a positive impact on public spending in both health and transport sectors and a negative impact on the energy sector expenditures. Nubukpo [10] used a standard model of growth to show that in the short term, total public spending have no significant impact on growth in the majority of countries of WAEMU, but in the long term the impact of total public spending on growth is strongly differentiated by country. 
It also concludes that government consumption expenditures have an overall negative impact UEMOA GDP in the short- and the long terms while public investment has a positive long-term impact. In the same vein, Coulibaly $M$ [12], using a Cobb-Douglas production function found a positive impact of public spending in education on economic growth in Côte d'Ivoire.

N'guessan [13] used a simple accelerator model in which it is assumed that technology of production is characterized by the fixed relationship between the desired capital stock and production level. Then, he concluded that public investment had a ripple effect on private investment in Côte d'Ivoire, Togo, and to the lesser extent in Niger. However, the ripple effect did not exist in Benin, Burkina Faso, Mali, and Senegal.

Ales Kuhar et al. [14] in an input-output model to study the outskirts of the Slovenia showed that public funds can stimulate economic growth in the peripheries of the Slovenia; however the national-level comparison shows that there are disparities between the regions.

Okoro A. S. [15] in a study on public spending in Nigeria concluded that in the long term there is a balance between public expenditure and economic growth and that the short-term dynamics adjusts to the long term equilibrium growth at a rate of $60 \%$ per year.

Ali Sulieman [16], in a study on public spending in Jordan showed that spending on capital and education does not lead to economic growth because education cost is not affordable. But health and economic business expenditures have an impact on economic growth.

Akonji, R. D et al. [17] have studied the relationship between public spending and economic growth by testing the Wagner Law. Using the Granger causality test, they concluded that total capital expenditures and GDP are in compliance with Wagner Law and following a one-way causality. On the other hand, periodic expenditures and GDP are linked in a two-way causation. But the link between periodic expenditures and GDP is the highest.

\section{Methodology}

This study relies on the empirical literature and the Rajhi model [2]. It is based on two methods of estimation. An error correction model will be estimated for each of the countries in which there is a presence of cointegration of variables, while for other countries we will estimate for each of them a VAR (pi) model, with $\mathrm{p}$ being the optimal lag of country i. The Generalized Moment Method (GMM) will be used for VAR models to address the endogeneity problem that can result from the presence of the endogenous variable among the explanatory variables [18]. Indeed, Arellano and Bond [19] showed that, is very likely to have a correlation between the dependent variable and the error terms, compromising the classical assumptions of the linear models, and thus the classical estimation methods such as the MCO are no longer appropriate [20]. The Generalized Moments Method proposed by Arrelano and Bond [19] help to control 
any problem of endogeneity due to the dependent variable, and to overcome the endogeneity issues.

\subsection{Presentation of the Theoretical Model}

Owing to the endogenous growth models of some authors as Romer [21], Rajhi [2] proposed a model of endogenous growth augmented by human capital and public spending. According to this author, factors such as physical capital $\left(k_{t}\right)$, human capital $\left(h_{t}\right)$ and the public good represented by government spending $\left(g_{t}\right)$ are the basic inputs in the production process; $t$ is the time dimension. In addition, this author believes that the accumulation of human capital is based on the time spent on training and research $\left(1-\mu_{t}\right)$. Thus, by taking into account this time dedicated to training, the equation for the training of human capital and research is as follows.

$$
h_{t}=B\left(1-u_{t}\right) h_{t}, 0<\mu_{t}<1
$$

Furthermore, the technology used in consumption goods sector is represented by a continuously twice differentiable function of production which has the three above-mentioned inputs. The Production per head is then represented by the following function:

$$
Y_{t}=f\left(k_{t} ; h_{t} ; u_{t} ; g_{t}\right)
$$

with $f_{k}, f_{h}, f_{g}>0$, the partial derivatives of the $y_{t}$ function with respect to $k_{t} h_{t}$ and $g_{t}$ respectively.

To obtain the analytical results comparable to those of Lucas [22] and Barro [1], the author describes the Equation (2) by a Cobb-Douglas production function such as:

$$
Y_{t}=f\left(k_{t} ; h_{t} ; u_{t} ; g_{t}\right)=A_{t} k_{t}^{\beta}\left(u_{t} h_{t}\right)^{(1-\beta)} g_{t}^{\gamma}
$$

with $0<\gamma<\beta<1$ and $A_{t}$ represents the technical progress. Applying the logarithm in Equation (3), we find the following expression that corresponds to the basic theoretical model:

$$
\ln Y_{t}=\ln A_{t}+\beta \ln k_{t}+(1-\beta) \ln \left(\mu_{t} h_{t}\right)+\gamma g_{t}
$$

\subsection{Empirical Model}

Several authors [10] [23] were interested in the origin of technical progress considered by Solow as being exogenous. These authors state that apart from the basic inputs (capital and labor), there are other factors that might explain the economic growth, and these factors can determine the technical progress. They can belong to the institutional, environmental, technological and demographic characteristics, etc. Given these assumptions, the generic form of technical progress can be written as follows (Table 1):

$$
A_{t}=A_{0} \mathrm{e}^{\sum_{i=1}^{k} a_{i} X_{i t}}
$$


Table 1. Description of variables.

\begin{tabular}{|c|c|}
\hline Variables & \\
\hline Pibh & Gross domestic product per capita \\
\hline Fbcf & Fixed gross capital formation (in \% of GDP) \\
\hline Dep & Public spending (in \% of GDP) \\
\hline Fbcfpub & $\begin{array}{l}\text { Gross fixed capital formation (in \% of GDP) i.e. } \\
\text { Public investment }\end{array}$ \\
\hline depcons & Public consumption (in \% of GDP) \\
\hline Credit & Domestic credit to private sector (in \% of GDP) \\
\hline Aide & Public aid to development (in \% GDP) \\
\hline Primaire & $\begin{array}{l}\text { Continuation of studies up to the end of primary } \\
\text { cycle ( } \% \text { of cohort ) }\end{array}$ \\
\hline Inflation & Inflation \\
\hline IDE & Foreign direct investment \\
\hline Labor & Labor force \\
\hline
\end{tabular}

By replacing (5) in (4) and noting $h_{t}^{*}=u_{t} h_{t}$ as the level of human capital used directly in production, we get the following general model for estimation purposes:

$$
\ln Y_{t}=\ln A_{0}+\sum_{i=1}^{k} a_{i} X_{i t}+\beta \ln k_{t}+\lambda \ln \left(\mu_{t} h_{t}\right)+\gamma g_{t}
$$

where $X_{i t}$ is a variable standing for institutions, demography, technology, business climate, etc., at time $t$ and $\lambda=1-\beta$. This Equation (6) can be rewritten in detailed form by introducing, in addition to the variable of interest (Government spending), other variables such as the primary completion rate to capture human capital, the foreign direct investment (FDI) to capture the business climate, the credit granted to the private sector, the public development aid and the inflation rate to understand the economic environment [10] [15] [23] [24]. Moreover, given that the model applies to countries observed over several years, it is introduced the index " $i$ ", in addition to the temporal index " $l$ ", to capture each country.

$$
\begin{aligned}
\ln \text { pibr }_{i t}= & \lambda_{0}+\lambda_{1} \ln \text { depbrut }_{i t}+\lambda_{2} \ln \text { fbcf }_{i t}+\lambda_{3} \ln \text { primaire }_{i t}+\lambda_{4} \ln \text { credit }_{i t} \\
& +\lambda_{5} \ln \text { inflation }_{i t}+\lambda_{6} \ln \text { aide }_{i t}+\lambda_{7} I D E_{i t}+\mu_{i t}
\end{aligned}
$$

where $\mu_{i t}$ represents the error term. Finally, this model (7) is to be estimated.

\subsection{Data Source}

All the data used come from the World Bank data, and they concern 10 countries of ECOWAS (Benin, Côte d'Ivoire, Burkina Faso, Ghana, Nigeria, Niger, Senegal, Guinea Conakry, Togo and Mali) over the period 1990-2015. Table 2 provides the descriptive statistics of the data over all the countries.

\subsection{Correlation Matrix of the Variables}

In parenthesis are the p-values. There is a negative and significant relationship between government spending variables. Moreover, the coefficients of correlation between explanatory variables are low, even if they are significant for some of the relationships, which implies a weak risk of multi-collinearity (Table A1). 
Table 2. Statistics of the data.

\begin{tabular}{cccccc}
\hline Variable & Observation & Mean & Std. Dev. & Min & Max \\
\hline lpibhbt & 312 & 6.630537 & 0.5865463 & 5.775017 & 8.072391 \\
lfbcf & 312 & 2.861692 & 0.4347634 & 1.51787 & 3.660878 \\
llabor & 312 & 4.19826 & 0.1576008 & 3.892126 & 4.426104 \\
laide & 312 & 1.833439 & 0.9809856 & -0.9816778 & 3.423393 \\
ldep & 312 & 4.679455 & 0.0950564 & 4.218328 & 4.886409 \\
lcredit & 312 & 2.591606 & 0.6517952 & 1.137447 & 4.271626 \\
\hline
\end{tabular}

\subsection{Specification and Tests of the Empirical Model}

\subsubsection{Test of HSIAO}

This test helps to decide on the application of a panel model when we are in the presence of data for several individuals during several periods. Also, it allows seeing whether the data generating process is homogeneous or heterogeneous. Econometrically speaking, Hsiao tests the equality of the coefficients of the model studied in its individual dimension. From an economic point of view, this test leads to decide on the nature of the chosen model. In other words, it allows seeing if the template in question can be considered to be identical for all individuals or not [25]. Its implementation is summarized in three steps (Figure A1).

The specification test of Hsiao is summarized in Table 3.

From the above table, Hsiao test results do not allow to accept at $5 \%$ threshold the null hypothesis as well at the first step as at the second. A panel estimate is not justified for the countries studied. So, the estimate will be done country by country.

\subsubsection{Test of Stationarity}

The test of stationarity is very important in Econometrics of time series. Studies have shown that a linear regression on non-stationary variables is often misleading as the distribution of the parameters follows more a Brownian movement rather than a Student law. The Stationarity of the series also plays an important role to make a good prediction. Studying the Stationarity of panel data allows to increase the size of the sample in a big way so that that to reduce the probability of dealing with structural breaks and to better address the problem of low power when testing small sample [26]. They increase the number of observations and the power of the tests by using the individual dimensions.

There are several methods to test the stationarity of panel data. But in this analysis, we will focus on four (4) methods including IPS, Hadri, Phillips Perron, LLC, and Breitung tests to ensure the robustness of the results.

After testing, it is apparent that all the variables are integrated of order 1 with the exception of public spending, inflation, IDEs (FDI) and public development aid which are stationary (Table A2). These results lead us to conduct cointegration tests in order to choose the appropriate model. 
Table 3. HSIAO specification test.

\begin{tabular}{cccc}
\hline & F-stat & P-value & Décision \\
\hline 1st step & 1.519 & 0.000 & We reject H0 \\
2 nd step & 1.328 & 0.057 & We reject H0 \\
\hline
\end{tabular}

Source: Calculation of the author.

\subsubsection{Cointegration Test}

The study of cointegration between variables allows checking the existence of long-term relationships. Several approaches have been proposed including those of Pedroni [27], Johansen [28], and Pesaran et al. [29]. Apart the approach by Pesaran et al., others require that the series are all integrated of order 1, that is not always the case and it is a limit for the analysis of time series and panel data. In addition, the statistics are not reliable for the case of small sample size. To avoid these limitations we rely on the approach of Pesaran et al. [29] by using an Autoregressive Distributed Lagged (ARDL) Model to test the significance of the coefficients of the variables in level. When these coefficients are jointly and significantly null, we accept the absence of cointegration.

The use of this model allows introducing of lagged explained and explanatory variables to capture the dynamic effects. In addition, it can be applied regardless of the fact that the explanatory variables are I (0) or I (1) or mutually cointegrated. Just make sure that the order of integration of the explanatory variables is less than or equal to one (1), and especially that the variable of interest is integrated of order one (1). The threshold test procedure used by Pesaran et al. is more robust for the study of small samples [29] [30]. It provides estimators of long term coefficients without bias, valid and robust t-statistics in the case of endogeneity of explanatory variables [29] [31] [32] [33]. However, the ARDL cointegration test assumes there is only one long term relationship between the explained and the exogenous variables [29]. After simulations, we have retained the ARDL model with constant and without trend for each country: The test results are compiled in Table 4.

Results show the existence of a cointegration relationship in Benin, Burkina Faso, Côte d'Ivoire, Guinea, Mali and Niger. For Ghana, Nigeria, Senegal and Togo i.e. the test does not reject the null hypothesis of absence of cointegration. Therefore, an error correction model will be estimated for each of the countries where there is presence of cointegration while for other countries, we will estimate for each of them a VAR (pi) model, where $p$ is the optimal lag of country $i$. The method of generalized moments will be used to estimate the VAR models and to address the endogeneity problem that can result from the presence of the endogenous variable among the explanatory variables. In the first case, the specification of the model is presented as follows:

$\checkmark$ Long-term relationship

$$
\text { lpibhbt }_{i t}=\vartheta_{i 1} l_{\text {dep }}+\vartheta_{i 2} l f b c f_{i t}+\vartheta_{i 3} \text { llabor }_{i t}
$$


Table 4. Cointegration tests results.

(a)

\begin{tabular}{cccccccc}
\hline & $10 \%$ & \multicolumn{3}{c}{$5 \%$} & \multicolumn{2}{c}{$\mathbf{2 . 5 0 \%}$} & \multicolumn{2}{c}{$1 \%$} \\
\hline low & High & low & high & & low high & low & high \\
2.72 & 3.77 & 3.23 & 4.35 & 3.69 & 4.89 & 4.29 & 5.61 \\
\hline
\end{tabular}

(b)

\begin{tabular}{cccccccccccc}
\hline Pays & BEN & BFA & CIV & GHA & GIN & MAR & MLI & NGA & NER & SEN & TOG \\
\hline F-stat computed & 197.808 & 9.173 & 55.99 & 0.853 & 75.512 & 8.742 & 5.23 & 3.261 & 7.382 & 0.521 & 0.557 \\
ARDL optimal & $(3,3,3,3)$ & $(1,3,2,3)$ & $(3,3,3,3)$ & $(1,1,1,1)$ & $(3,2,2,3)$ & $(3,3,2,3)$ & $(3,3,3,2)$ & $(3,3,3,2)$ & $(3,2,2,2)$ & $(1,1,1,1)$ & $(1,2,3,3)$ \\
\hline
\end{tabular}

Source: Author calculations.

Avec $\vartheta_{0}=-\frac{\alpha_{0}}{\alpha_{1}} ; \vartheta_{1}=-\frac{\alpha_{2}}{\alpha_{1}} ; \vartheta_{2}=-\frac{\alpha_{3}}{\alpha_{1}} ; \vartheta_{3}=-\frac{\alpha_{4}}{\alpha_{1}}$

For the long term we assume, $l p i b h b t_{i t}=l p i b h b t_{i t-j} ; \quad l d e p_{i t}=l d e p_{i t-j}$; $l f b c f_{i t}=l f b c f_{i t-j} ; \quad l l a b o r_{i t}=$ llabor $_{i t-j}$

\section{$\checkmark$ Short term relationship}

$$
\begin{aligned}
& \Delta \text { lpibhbt }_{i t}=\alpha_{i}+\lambda_{i} E C M_{i t-1}+\sum_{j=1}^{p-1} \beta_{i j} \Delta l p i b h b t_{i t-j}+\sum_{j=0}^{q 1-1} \gamma_{j} \Delta l d e p_{i t-j} \\
& +\sum_{j=0}^{q 2-1} \delta_{j} \Delta l f b c f_{i t-j}+\sum_{j=0}^{q 3-1} \mu_{j} \Delta \text { llabor }_{i t-j}+\tau_{i t}
\end{aligned}
$$

where $\lambda_{i} E C M_{i t-1}$ is the adjustment of the dependent variable to its long run equilibrium. For the model to be valid and significant, the coefficient $\lambda_{i}$ as the adjustment speed measure must be negative and less than 1 in absolute value. To this model, we add other exogenous variables as mentioned above in the methodology; variables which are likely to influence the economic growth of ECOWAS countries. Finally, the short term model can be written as follows:

$$
\begin{aligned}
\Delta \text { lpibhbt }_{i t}= & \alpha_{i}+\lambda_{i} E \text { CM }_{i t-1}+\sum_{j=1}^{p-1} \beta_{i j} \Delta \text { lpibhbt }_{i t-j}+\sum_{j=0}^{q 1-1} \gamma_{j} \Delta \text { Llep }_{i t-j} \\
& +\sum_{j=0}^{q 2-1} \delta_{j} \Delta f b c f_{i t-j} \sum_{j=0}^{q 3-1} \mu_{j} \Delta \text { llabor }_{i t-j}+\delta_{i 1} \text { laide }_{i t}+\delta_{i 2} \text { infl }_{i t} \\
& +\delta_{i 3} \text { ide }_{i t}+\delta_{i 4} \Delta \text { lcredit }_{i t}+\delta_{i 4} \text { sprim }_{i t}+\tau_{i t}
\end{aligned}
$$

In the second case, the VAR model (pi) is written as:

$$
\begin{aligned}
& \Delta \text { slpibhbt }_{i t}=\alpha_{i}+\sum_{j=1}^{p} \beta_{i j} \Delta \text { lpibhbt }_{i t-j}+\sum_{j=0}^{q i} \gamma_{j} \Delta l d e p_{i t-j}+\sum_{j=0}^{q i} \delta_{j} \Delta f b c f_{i t-j}+\sum_{j=0}^{q i} \mu_{j} \Delta \text { llabor }_{i t-j} \\
& +\delta_{i 1} \text { laide }_{i t}+\delta_{i 2} \text { infl }_{i t}+\delta_{i 3} \text { ide }_{i t}+\delta_{i 4} \Delta \text { crredit }_{i t}+\delta_{i 4} \Delta \operatorname{prim}_{i t}+\tau 1_{i t} \\
& \Delta l d e p_{i t}=\alpha_{i}+\sum_{j=1}^{p} \beta_{i j} \Delta \text { lpibhbt }_{i t-j}+\sum_{j=1}^{q i} \gamma_{j} \Delta l d e p_{i t-j}+\sum_{j=1}^{q i} \delta_{j} \Delta l f b c f_{i t-j}+\sum_{j=1}^{q i} \mu_{j} \Delta l l a b o r_{i t-j} \\
& +\delta_{i 1} \text { laide }_{i t}+\delta_{i 2} \text { infl }_{i t}+\delta_{i 3} \text { ide }_{i t}+\delta_{i 4} \Delta \text { lcredit }_{i t}+\delta_{i 4} \Delta \operatorname{prim}_{i t}+\tau 2_{i t} \\
& \Delta l f b c f_{i t}=\alpha_{i}+\sum_{j=1}^{q i} \beta_{i j} \Delta l p i b h b t_{i t-j}+\sum_{j=1}^{q i} \gamma_{j} \Delta l d e p_{i t-j}+\sum_{j=1}^{q i} \delta_{j} \Delta l f b c f_{i t-j}+\sum_{j=1}^{q i} \mu_{j} \Delta l l a b o r_{i t-j} \\
& +\delta_{i 1} \text { laide }_{i t}+\delta_{i 2} \text { infl }_{i t}+\delta_{i 3} \text { ide }_{i t}+\delta_{i 4} \Delta \text { lcredit }_{i t}+\delta_{i 4}{ }_{\text {prim }}+\tau{ }_{i t}+\tau 3_{i t} \\
& \Delta \text { llabor }_{i t}=\alpha_{i}+\sum_{j=1}^{q i} \beta_{i j} \Delta \text { lpibhbt }_{i t-j}+\sum_{j=1}^{q 1} \gamma_{j} \Delta l d e p_{i t-j}+\sum_{j=1}^{q i} \delta_{j} \Delta l f b c f_{i t-j}+\sum_{j=1}^{q i} \mu_{j} \Delta l l a b o r_{i t-j} \\
& +\delta_{i 1} \text { laide }_{i t}+\delta_{i 2} \text { infl }_{i t}+\delta_{i 3} \text { ide }_{i t}+\delta_{i 4} \Delta \text { lcredit }_{i t}+\delta_{i 4} \Delta \text { prim }_{i t}+\tau 4_{i t}
\end{aligned}
$$




\section{Presentation and Analysis of the Results}

\subsection{Impact of Total Government Spending on the Economic Growth of ECOWAS Countries}

\subsubsection{ARDL Model Analysis (Table 5)}

The results show the presence of an error correction mechanism in 6 out of 11 cases. All the coefficients of adjustments are negative and significantly lower than 1 in absolute value with a slight overflow of 0.2 point for Niger. This result assumes for these countries, that the variables have a same trend in the long term. The estimated value of the coefficient of the error correction term (ECM) informs about the speed of the adjustment process to the long run equilibrium after a short-term shock. In Benin, this coefficient is equal to 0.333; that means that approximately $33 \%$ of disequilibrium due to a shock is corrected one year after. In other words, a deviation from the long run following a short term shock is corrected approximately by $33 \%$ a year after. This coefficient is respectively 0,299; 0,779; 0.234 and 0.79 for Burkina Faso, Côte d'Ivoire, Guinea, and Mali.

Table 5. Results from the ARDLmodel.

\begin{tabular}{|c|c|c|c|c|c|c|c|c|c|c|}
\hline & BEN & BFA & CIV & GHA & GIN & MLI & NGA & NER & SEN & TOG \\
\hline & Coef & Coef & Coef & Coef & Coef & Coef & Coef & Coef & Coef & Coef \\
\hline $\mathrm{ce}$ & $-0.333^{* *}$ & $-0.299^{\star * *}$ & $-0.779^{\star *}$ & -0.075 & $-0.234^{\star *}$ & $-0.791^{* *}$ & 0.444 & $-1.248^{* *}$ & -0.155 & -0.528 \\
\hline \multicolumn{11}{|c|}{ LONG TERM } \\
\hline ldept & $-1.425^{\star *}$ & $5.801^{\star *}$ & $1.328^{* * *}$ & -0.774 & $2.161^{\star *}$ & $-3.000^{* * *}$ & -3.155 & $-2.38^{\star \star}$ & 0.547 & 0.785 \\
\hline llabort & $-4.758^{\star \star}$ & $293.625^{\star \star \star}$ & $-19.499^{* * *}$ & -1.536 & $7.025^{\star * *}$ & $1.111^{\star *}$ & -5.208 & -1.064 & -0.796 & -6.152 \\
\hline \multicolumn{11}{|c|}{ SHORT TERM } \\
\hline dlppibhbtt-1 & $-0.257^{\star \star}$ & - & 0.096 & - & 0.057 & $0.816^{*}$ & 1.906 & 0.14 & - & 0.918 \\
\hline dlppibhbtt-2 & $0.98^{\star * *}$ & - & $-0.69^{\star *}$ & - & $0.136^{*}$ & 0.374 & -0.342 & -0.492 & - & - \\
\hline dldept-1 & $0.558^{\star \star}$ & -0.443 & $-0.319^{*}$ & - & $-0.756^{* * *}$ & $1.983^{\star *}$ & $-0.979^{* *}$ & $1.626^{*}$ & - & -2.125 \\
\hline dldept-2 & $0.992^{* * *}$ & -1.069 & 0.087 & - & - & $1.568^{\star *}$ & $-0.625^{\star}$ & - & - & - \\
\hline $\mathrm{dlfbcft}$ & 0.0345 & $0.146^{\star *}$ & $-0.175^{\star *}$ & - & $-0.112^{* * *}$ & $-0.301^{\star}$ & 0.222 & $-0.422^{\star *}$ & - & 0.079 \\
\hline dlfbcft-1 & $-0.056^{*}$ & $0.092^{\star *}$ & $-0.106^{\star *}$ & - & $-0.15^{\star * *}$ & -0.147 & $-0.198^{*}$ & $-0.25^{\star}$ & - & 0.249 \\
\hline dlfbcft-2 & $-0.174^{* * *}$ & - & $0.039^{\star *}$ & - & - & -0.181 & -0.129 & - & - & 0.264 \\
\hline dllabort & $-10.899^{\star * *}$ & $-133.048^{\star * *}$ & $-12.44^{\star *}$ & - & $-2.767^{\star * *}$ & $\star-1.787$ & $-114.519^{\star *}$ & $43.736^{\star}$ & - & -54.066 \\
\hline dllabort-1 & $16.694^{\star * *}$ & $-100.909^{* * *}$ & -3.11 & - & $-4.076^{* * *}$ & -1.135 & $67.464^{*}$ & -17.001 & - & 115.782 \\
\hline dllabort-2 & $-3.903^{\star *}$ & $-45.795^{\star *}$ & $29.6^{* *}$ & - & $-3.654^{\star * *}$ & - & - & - & & $-84.514^{*}$ \\
\hline IDEt & $0.012^{\star * *}$ & -0.001 & $-0.031^{\star *}$ & -0.001 & $0.003^{* * *}$ & -0.001 & 0.014 & -0.0001 & 0.002 & 0.0019 \\
\hline laidet & 0.012 & $-0.093^{* * *}$ & -0.003 & -0.044 & $0.049^{\star * *}$ & 0.129 & $0.108^{\star}$ & 0.046 & 0.006 & -0.016 \\
\hline dprim & $0.007^{\star * *}$ & -0.003 & $-0.001^{\star}$ & 0.003 & $0.002^{* * *}$ & $0.026^{\star *}$ & $-0.011^{\star}$ & -0.001 & 0.0002 & -0.0116 \\
\hline dlcreditt & $0.034^{\star *}$ & $-0.119^{\star *}$ & 0.0189 & -0.118 & $0.013^{*}$ & -0.115 & 0.073 & -0.042 & -0.054 & -0.319 \\
\hline cons & $10.919^{*}$ & $-394.084^{\star * *}$ & $64.166^{\star *}$ & 1.259 & $-8.636^{\star * *}$ & $11.891^{\star *}$ & -18.909 & $24.826^{\star *}$ & 1.101 & 15.763 \\
\hline
\end{tabular}

Source: author estimations. 


\section{1) Analysis of the Long-Term Relationship}

In the long-term, the Total Government Spending negatively impacts the economic growth in Benin, Mali and Niger while this impact is rather positive in Burkina Faso, Ivory Coast and Guinea.

On the other hand, economic growth is positively impacted by physical capital (GFCF) in the short term for the majority of the countries except Burkina Faso where the relationship between the two variables is negative in the long run while it is positive in the short term.

Labor factor is also a determinant factor on which policy-makers must rely on to set up sustained economic growth. The results show that there is a positive relationship between labor factor and economic growth in Burkina Faso, Mali and Guinea, while this relationship is rather negative for Benin and Ivory Coast.

\section{2) Analysis of the Short-Term Relationship}

In the short term, the Total Government Spending negatively influences economic growth in Benin, Burkina Faso, Côte d'Ivoire and Guinea Conakry. However, this relationship is positive for Mali and Niger. These results again draw attention to the controversy that exists around the causality between governments spending and economic growth, causality which varies according to the specificities of the studied countries.

Furthermore, the analysis shows that Foreign Direct Investment has a positive effect in the growth of Benin and Guinea while this effect is negative in Côte d'Ivoire. However, the effect of the FDI seems to be not significant in Burkina Faso, Mali and Niger.

This negative relationship of FDI on the economic growth can be explained by the absence of enough skilled labor force to attract foreign investors and boost the economic growth in the countries of the sample. Actually, with the exception of Niger, labor factor has a negative and significant effect on economic growth.

In Benin and Guinea, the economic growth is influenced negatively by inflation while in other countries, the effect is not significant. Regarding international aid variable, the results confirm what is generally found in the literature. Indeed, this variable has a negative effect on economic growth of Burkina Faso and the Niger. On the other hand, in Guinea, international aid has a positive and significant effect on economic performance while this effect is not significant in Benin, Ivory Coast to Mali and the Niger. In fact, according to Burnside \& Dollar (2000), international aid is not in itself a negative factor for economic growth but, it would be effective and positively impact economic growth in countries with "good" institutions and sound economic policies.

\subsubsection{The VAR Model Analysis}

The Negative Impact of Total Government Spending on Economic Growth in Togo, Nigeria, Senegal and Ghana

The hypothesis of absence of cointegration is not rejected for Togo, Senegal, Nigeria and Ghana. So, a VAR model was estimated with the GMM method to address the problem of endogeneity that results from the dependent variable which 
also stands as one of the explanatory variables. The VAR stationarity tests show that the variables are stationary for each of the four (4) countries, since all unit roots are lower than the unit in module (or are contained in the unit circle).

The influence of public spending in Togo, Senegal and Ghana is highlighted through a VAR model (Table A3); economic growth is negatively affected by Total Public Spending in these countries. For Nigeria, the coefficients are negative but not significant.

The gross fixed capital formation is a factor on which Togo and Senegal can rely in the short term to boost their economic growth. Labor factor also plays a positive and significant role in Togo and Ghana, but it requires a better quality to ensure sustained economic growth. In addition, a favorable environment for business and proper financial institutions are needed to allocate beneficial loans to the private sector and to attract FDIs.

Moreover, inflation has a negative effect on the economic growth of the countries of the sample. This highlights the interest to control inflation to ensure a sound economic growth.

\subsection{The Impact Public Consumption Expenditures on Economic Growth of ECOWAS Countries}

\subsubsection{The ARDL Model Analysis}

Table 6 shows the existence of long-term relationship between public consumption (depcons) and growth for Benin, Burkina Faso, Côte d'Ivoire, Guinea Conakry, Mali and Niger. Moreover, the adjustment coefficient of the error term is negative and significant for each of these countries.

1) Owing to the Long Term Model Public Consumption Spending Negatively Influences Economic Growth in Most of the Countries

In the long run, government expenditures have a negative impact in Niger and Guinea while they have a positive and significant effect in Ivory Coast. In the other remaining countries, the effect is not significant.

However, investment represented here by the Gross Fixed Capital Formation (GFCF) usually influences economic growth in a positive way in the long term. Indeed, among 7 selected countries, 2 are positively impacted by the GFCF (Côte d'Ivoire and Guinea) and only 1 (Burkina Faso) is negatively impacted. This can be explained by the fact that this country is so far dealing with a socio-political crisis and has been experiencing terrorist threats that have created a unfavorable climate for FDIs. As pointed out by several authors, as long as there is no socio-political and economic stability and good institutions, investment and international aid efforts cannot positively impacts the economy.

2) In the Short Term Government Consumption Is a Stimulating Factor of Economic Growth

In the short term, public consumption generally boosts the economy, which confirms the Keynesian thesis that explains government spending and budget deficit have a positive effect on GDP growth. Indeed, in four (4) countries (Benin, Côte d'Ivoire, Guinea and Niger) where the effect is significant, only Ivory 
Coast is negatively impacted in the short run, while in the long run public spending has a positive effect in this country. This can be explained by the fact that Ivory Coast has just went through a decade of social and political unrest that undermined its economy. But this country is doing so much investment to repair the damages created by the civil war in order to put the economy in a sustainable growth path.

Table 6. Estimation results public consumption and growth from the ARDL model.

\begin{tabular}{|c|c|c|c|c|c|c|c|}
\hline & BEN & BFA & CIV & GIN & MAR & MLI & NER \\
\hline & Coef & Coef & Coef & Coef & Coef & Coef & Coef \\
\hline $\mathrm{ce}$ & $-0.769^{* *}$ & $-0.139^{* *}$ & $-1.003^{* * *}$ & $-0.274^{\star *}$ & $-0.285^{\star *}$ & $-0.411^{*}$ & $-0.663^{*}$ \\
\hline \multicolumn{8}{|c|}{ Long term } \\
\hline ldepconst & 0.009 & 0.045 & $0.115^{\star \star \star}$ & $-0.238^{\star}$ & -0.585 & -0.204 & $-0.419^{\star}$ \\
\hline $1 \mathrm{fbcft}$ & 0.112 & $-1.435^{\star \star}$ & $0.335^{\star * *}$ & $1.459^{*}$ & $1.673^{\star}$ & -0.533 & 0.004 \\
\hline llabort & $-6.42^{\star *}$ & $300.381^{\star * *}$ & $-14.390^{\star * *}$ & $10.149^{* *}$ & 0.111 & $1.876^{* *}$ & $-3.709^{* *}$ \\
\hline \multicolumn{8}{|c|}{ Short term } \\
\hline dlpibhbtt-1 & 0.508 & - & 0.275 & - & -0.353 & $1.418^{\star \star}$ & $-1.071^{\star *}$ \\
\hline \multicolumn{2}{|c|}{ dlpibhbtt-2 } & - & - & - & -0.495 & $0.818^{\star *}$ & -0.084 \\
\hline dldepconst & $0.054^{* *}$ & - & $-0.084^{* * *}$ & $0.057^{\star * *}$ & -0.233 & 0.033 & $0.217^{\star * *}$ \\
\hline dldepconst-1 & 0.021 & - & $-0.066^{* * *}$ & $0.045^{\star * *}$ & -0.202 & 0.02 & $0.137^{\star \star}$ \\
\hline \multicolumn{2}{|c|}{ dldepconst-2 } & - & $-0.037^{\star * *}$ & - & -0.109 & -0.018 & $0.069^{\star *}$ \\
\hline $\mathrm{dlfbcft}$ & 0.008 & 0.064 & $-0.126^{\star *}$ & $-0.231^{\star * *}$ & -0.056 & 0.218 & -0.104 \\
\hline dlfbcft-1 & 0.079 & $0.079^{*}$ & $-0.071^{\star *}$ & $-0.258^{* * *}$ & -0.446 & 0.144 & 0.036 \\
\hline dlfbcft-2 & -0.031 & - & & -0.046 & - & -0.075 & $0.152^{\star}$ \\
\hline dllabort & -4.166 & $-82.639^{* * *}$ & $-24.080^{\star *}$ & $-4.942^{\star * *}$ & 0.277 & 1.048 & -31.993 \\
\hline dllabort-1 & $7.511^{\star}$ & $-58.232^{\star \star}$ & -0.135 & $-4.196^{* * *}$ & 0.316 & -1.541 & 28.005 \\
\hline dllabort-2 & & -19.806 & $25.246^{\star *}$ & $-4.089^{* * *}$ & 1.31 & $-1.224^{\star}$ & $-27.493^{\star}$ \\
\hline IDEt & 0.005 & $-0.009^{\star}$ & -0.005 & $-0.005^{\star * *}$ & $0.017^{\star \star}$ & $-0.017^{\star *}$ & $-0.009^{\star *}$ \\
\hline laidet & -0.037 & $-0.052^{\star *}$ & 0.006 & $0.037^{\star * *}$ & -0.034 & -0.063 & $-0.167^{\star *}$ \\
\hline Inf_pibt & $-0.002^{\star * *}$ & 0.001 & $-0.002^{* * *}$ & $-0.002^{* * *}$ & $-0.012^{\star *}$ & -0.001 & $0.004^{\star *}$ \\
\hline dprim & $0.004^{* *}$ & 0.001 & 0.0002 & $0.001^{\star *}$ & -0.002 & $0.015^{\star *}$ & 0.002 \\
\hline dlcreditt & $-0.032^{\star *}$ & -0.029 & 0.0189 & -0.031 & $-0.279^{\star *}$ & -0.09 & -0.012 \\
\hline cons & $25.988^{\star *}$ & $-183.268^{\star *}$ & $66.535^{\star *}$ & $-10.923^{\star * *}$ & 1.463 & -0.679 & 15.988 \\
\hline
\end{tabular}

Source: author calculations. 


\subsubsection{VAR Modeling}

The VAR analysis reveals the existence of a positive and significant relationship between Public Consumption Spending and economic growth in Togo and Senegal (Table A4). Also the economy of these two countries is positively impacted by private investment. These results are similar to those previously obtained and confirm the economic theory.

\subsection{Impact of Public Investment on the Economic Growth of the ECOWAS Countries}

In this part, the analysis only covers 8 out of 15 countries due to the lack of data. Cointegration tests show the existence of a long-term relationship between investment and growth in Burkina Faso, Ivory Coast and Ghana, which allows us to estimate an ARDL model for each of these countries. However, for countries like Benin, Niger, Guinea, Senegal and Togo there is no long-term relationship. So, a VAR model will be estimated for these countries.

\subsubsection{The ARDL Model Analysis}

Estimation results of the ARDL model presented in Table 7 show a negative and significant adjustment coefficient which is less than 1 in absolute value; this gives evidence of the long term relationship between the dependent variable and the explanatory variables.

1) Long Term Relationship: Positive Impact of Public Investment on Economic Growth

In the long run, the results show a positive and highly significant public investment (fbcfpub) impact on economic growth of Burkina Faso, Ivory Coast and Ghana. However, the effect is more important in Côte d'Ivoire (0.316) compared to Ghana (0.211) and Burkina Faso (0.065).

2) Short term Relationship: Negative Impact of Public Investment on Economic Growth

In the short term, public investment adversely affects economic growth. This can be caused by the fact that investment at a time $t$ accuses a slight delay before producing positive effects. The negative effect in the short term can also results from the fact that public investment requires additional public expenditure that can negatively affect the government budget balance, and then the all economy. One would wait a few years for getting positive effect on economic growth.

\subsubsection{VAR Modeling}

\section{1) Estimation Results for Benin, Guinea, Niger, Senegal and Togo}

Public investment did not significantly influence economic growth in Benin, Guinea, the Niger, Senegal and Togo (Table A5). However, we can see in Benin that investment after two years period has a positive impact on economic growth. Efforts should be done to direct investments to the best performing sectors of the economy and create the needed infrastructures so that investment can become productive. 
2) Shock on Total Government Spending and Economic Growth in Togo, Senegal, Ghana and Nigeria

Analysis of impulse response function shows that following a shock on Total Public Spending, there is a slowdown in economic growth in Ghana, Nigeria and Senegal in the first year while in Togo, a shock on the public spending has a positive short-term effect. Note that from the second year, there is a strong GDP growth in Nigeria while this trend is less pronounced in other countries (Figure $1)$.

Table 7. Esimation results Public Investment and growth from ARDL model.

\begin{tabular}{|c|c|c|c|}
\hline & BFA & CIV & GHA \\
\hline & Coef & Coef & Coef \\
\hline ce & $-0.213^{* * *}$ & $-0.591^{\star *}$ & $-0.463^{* * *}$ \\
\hline \multicolumn{4}{|c|}{ Long term } \\
\hline ldepconst & 0.431 & 0.037 & 0.016 \\
\hline lfbcfpubt & $0.065^{\star * *}$ & $0.316^{\star *}$ & $0.211^{* * *}$ \\
\hline llabort & $170.989^{* * *}$ & $-23.774^{* *}$ & $2.615^{\star * *}$ \\
\hline \multicolumn{4}{|c|}{ Short term } \\
\hline dlppibhbtt-1 & $0.377^{* *}$ & - & - \\
\hline dlppibhbtt-2 & $0.287^{\star}$ & - & - \\
\hline dldepconst & - & - & 0.007 \\
\hline dldepconst-1 & - & - & - \\
\hline dldepconst-2 & - & - & - \\
\hline dlfbcfpubt & -0.008 & $-0.138^{* * *}$ & $-0.087^{\star * *}$ \\
\hline dlfbcfpubt-1 & - & $-0.087^{\star * \star}$ & $-0.039^{* * *}$ \\
\hline dlfbcfpubt-2 & - & -0.018 & $-0.017^{\star *}$ \\
\hline dllabort & $-62.024^{* * *}$ & $31.898^{*}$ & -2.248 \\
\hline dllabort-1 & - & -10.379 & - \\
\hline dllabort-2 & - & $71.677^{\star *}$ & - \\
\hline IDEt & $-0.132^{\star \star *}$ & -0.035 & 0.001 \\
\hline laidet & $-0.052^{\star \star}$ & 0.023 & $-0.063^{*}$ \\
\hline Inf_pibt & 0.001 & 0.002 & $0.001^{*}$ \\
\hline dprim & 0.002 & -0.0001 & $0.001^{* *}$ \\
\hline dlouvert & -0.079 & $-0.353^{* *}$ & $-0.145^{\star *}$ \\
\hline cons & $-160.858^{* * *}$ & $62.381^{\star *}$ & $-2.274^{*}$ \\
\hline
\end{tabular}

Source: author calculations. 


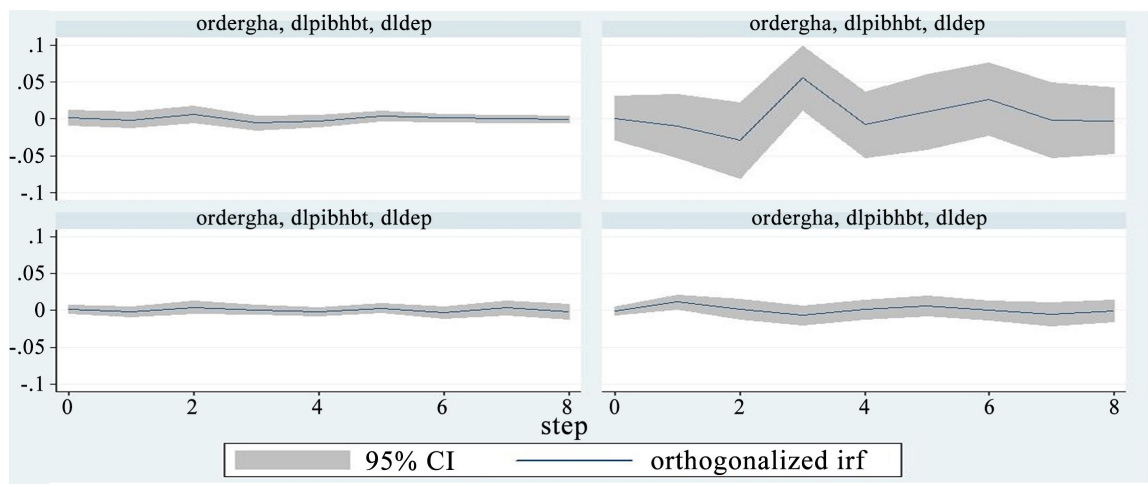

Figure 1. Impact of public spending shock on economic growth in Ghana, Nigeria, Senegal and Togo. Source: author simulations.

\subsection{Results Summary Table}

(Yes = positive impact on economic growth)

\begin{tabular}{|c|c|c|c|c|c|c|}
\hline & \multicolumn{3}{|c|}{ SHORT TERM } & \multicolumn{3}{|c|}{ LONG TERM } \\
\hline & $\begin{array}{c}\text { TOTAL } \\
\text { PUBLIC } \\
\text { SPENDING }\end{array}$ & $\begin{array}{c}\text { PUBLIC } \\
\text { CONSUMPTION }\end{array}$ & $\begin{array}{c}\text { PUBLIC } \\
\text { INVESTMENT }\end{array}$ & $\begin{array}{c}\text { TOTAL } \\
\text { PUBLIC } \\
\text { SPENDING }\end{array}$ & $\begin{array}{c}\text { PUBLIC } \\
\text { CONSUMPTION }\end{array}$ & $\begin{array}{c}\text { PUBLIC } \\
\text { INVESTMENT }\end{array}$ \\
\hline BENIN & NO & YES & & NO & & \\
\hline BURKINA & NO & & & YES & & YES \\
\hline COTE D'IV & NO & NO & NO & YES & YES & YES \\
\hline GHANA & NO & & NO & & & YES \\
\hline MALI & YES & & & NO & & \\
\hline NIGER & YES & NO & & NO & YES & \\
\hline GUIN & NO & YES & & YES & YES & \\
\hline \multicolumn{7}{|l|}{ NGA } \\
\hline SEN & NO & YES & & & & \\
\hline TOG & NO & YES & & & & \\
\hline
\end{tabular}

The cells in gray indicate either the absence of long term relationship for the country in question or the fact that the country has been excluded from the analysis due to the lack of data. The empty white cell means that the coefficient of the variable is not significant.

\section{Conclusions}

The introduction of government spending in endogenous growth models is a topic of great importance for public economics. We analyzed the impact of government spending on economic growth in 10 countries in West Africa using an endogenous growth model augmented of government expenditure and developed by Rajhi (1996).

After the stationarity and cointegration tests, either an ARDL error correction 
model or a VAR model has been estimated, by using the estimation method that best fits the econometric analysis of each country.

Results give evidence that Total Government Spending does not positively affect economic growth in most of the countries of the sample as well in the short term as in the long term. Burkina Faso, Guinea and Ivory Coast are the three excepted countries in which Total Public Spending has a positive effect on GDP growth in the long term. For further analysis we looked at Public Consumption and Public Investment.

It is only in four out of ten countries of the sample we found that Public Consumption expenditures positively affect economic growth in the short term while the impact generally is negative in the long term.

Regarding Public investment, it is only in three out of ten countries (Burkina Faso, Côte d'Ivoire, Ghana), that it was found determinant to economic growth in the long term.

These results show that the ECOWAS countries are facing a problem of economic inefficiency in public spending. Social and political instability, bad governance, corruption, lack of transparency in the management of public procurement are the main factors of inefficiency in public spending. That's why we will give the following recommendations:

- First of all, we must strengthen the rule of law and democracy to create an environment and institutions that ensure the effectiveness of public action in general and fiscal policies in particular. It is a prerequisite for any effective economic policy.

- To rationalize public spending by priority choices and an efficient management of resources. Public policies must set out quantitative and qualitative objectives.

- To create a favorable business environment for public investment to attract national and foreign private investment.

- To ensure transparency in the allocation and implementation of public procurement according to the rules of competition. Indeed, because of the corruption, in most of the time, real values of expenditures are substantially lower than their nominal amounts in the budget.

- To avoid the excessive public deficit and unsustainable debt, this could result in the cause of socio-economic instability and crisis.

Like any study, this one has its limits related especially to the non-availability of data for all ECOWAS countries. Moreover, taking into account institutional quality variables would shed more light.

\section{Conflicts of Interest}

The author declares no conflicts of interest regarding the publication of this paper.

\section{References}

[1] Barro, R. (1990) Government Spending in a Simple Model of Endogenous Growth. 
Journal of Political Economy, 98, 103-125. https://doi.org/10.1086/261726 Barro, R. (1991) Economic Growth in a Cross Section of Countries. Quarterly Journal of Economics, 106, 407-443. https://doi.org/10.2307/2937943

[2] Rajhi, T. (1996) Dynamique des politiques de croissance. Economica, Paris, 274 p. https://doi.org/10.3917/econo.rajhi.1996.01

[3] Tanzi, V. and Zee, H. (1997) Fiscal Policy and Long-Run Growth. IMF Staff Papers, 44, 179-209. https://doi.org/10.2307/3867542

[4] Agenor, P.R. (2000) L'économie de l'ajustement et de la croissance, Mimeo, Washington, Banque Mondiale, 848 p.

[5] Devarajan, S., Swaroop, V. and Zou, H. (1996) The Composition of Public Expenditure and Economic Growth. Journal of Monetary Economics, 37, 318-344.

[6] Moussa, D.S. (2007) Dépenses publiques et croissance économique au Sénégal. mémoire de maîtrise.

[7] Taiwo, M. and Abayomi, T. (2011) Government Expenditure and Economic Development: Empirical Evidence from Nigeria. European Journal of Business and Management, 3, 18-28. https://mpra.ub.uni-muenchen.de/37293/

[8] Ojo, O. and Oshikoya, T. (1995) Determinants of Long Term Growth: Some African Results. Journal of African Economies, 4, 163-191. https://doi.org/10.1093/oxfordjournals.jae.a036830

[9] Tenouk, K. (1999) Les déterminants de la croissance à long terme dans les pays de l'UEMOA. Notes d'Information et Statistiques. Études et Recherches, 493, BCEAO, juin.

[10] Nubukpo, K.K. (2003) Dépenses publiques et croissance des économies de l'UEMOA. CIRAD Montpellier France.

[11] Keho, Y. (2007) Causal Relationship between Energy Consumption and GDP: An Empirical Analysis for Five West African Countries. The Journal of Energy and Development, 33, 23-32.

[12] Mamadou, C. (2013) Impact des dépenses publiques d'éducation sur la croissance économique en côte d'ivoire. European Scientific Journal, 9, 25.

[13] N'Guessan, B.A. (2007) Structure des dépenses publiques, investissement privé et croissance dans l'UEMOA. Document d'étude et de recherche No. DER/07/04Septembre.

[14] Kuhar, A., et al. (2005) Evaluation of Public Expenditure on Economic Growth of the Peripheral Slovenia with Input-Output Model. Acta Agriculturae Slovenica, 86, 49-61.

[15] okoro, A.S. (2013) Government Spending and Economic Growth in Nigeria (1980-2011). Global Journal of Management and Business Research, 13, 21-29.

[16] Al-Shatti, A.S. (2014) The Impact of Public Expenditures on Economic Growth in Jordan. International Journal of Economics and Finance, 6, 157-167.

[17] Akonji, D.R., Olateju, A.O. and Abba, M.W. (2013) Nexus between Public Expenditure and Economic Growth by Testing Wagner's Law Time Series: Evidence from Nigeria. International Journal of Development and Sustainability, 2, 2383-2395.

[18] Kangni, K. and Jeanneney, S.G. (2008) Financial Development and Poverty Reduction: Can There Be a Benefit without a Cost? International Monetary Fund (IMF).

[19] Manuel, A. and Bond, S. (1991) Some Tests of Specification for Panel Data: Monte Carlo Evidence and an Application to Employment Equations. The Review of Economic Studies, 58, 277-297. https://doi.org/10.2307/2297968 
[20] Robert and White, H. (2001) Are There Negative Returns to Aid? Journal of Development Studies, August, 37, 42-65. https://doi.org/10.1080/713601082

[21] Romer, P. (1990) Endogenous Technological Change. Journal of Political Economy, 98, S71-S102.

[22] Lucas, R.E. (1988) On the Mechanics of Economic Development. Journal of Monetary Economics, 22, 3-42. https://doi.org/10.1016/0304-3932(88)90168-7

[23] Kane, C.S. and Diop, A.N. (2012) Risque sociopolitique et investissements directs étrangers en Afrique de l'Ouest. West African Economic Review, 1.

[24] Bsiri, M. (2012) Impacts de la crise économique sur les pays d'Europe du Sud. Confluences Méditerranée, 80, 47-55.

[25] Luo, T., Zhu, Q. and Li, D. (2009) The Value Relevance of R\&D Expenditure in Chinese Public Companies. Journal of Financial Research, 6, 12.

[26] Baltagi Badi, H. and Kao, C. (2001) Non Stationary Panels, Cointegration in Panels and Dynamic Panels: A Survey. Non Stationary Panels, Panel Cointegration, and Dynamic Panels. Emerald Group Publishing Limited, 7-51.

[27] Pedroni, P. (1999) Fully Modified OLS for Heterogeneous Cointegrated Panels. Non Stationary Panels, Panel Cointegration, and Dynamic Panels. Emerald Group Publishing Limited, 93-130.

[28] Johansen, S. (1999) Estimation and Hypothesis Testing of Cointegration Vectors in Gaussian Vector Autoregressive Models. Econometrica: Journal of the Econometric Society, 59, 1551-1580.

[29] Pesaran, M.H., Shin, Y. and Smith, R.J. (2001) Bounds Testing Approaches to the Analysis of Level Relationships. Journal of Applied Econometrics, 16, 197-202. https://doi.org/10.1002/jae.616

[30] Cheonga, T.T. and Nair, M. (2002) A Cointegration Analysis of Malaysian Import Demand Function: Reassessment from the Bounds Test. Applied Economics Letters, 9, 293-296. https://doi.org/10.1080/13504850110073471

[31] Brett, I. (1993) Estimating Long-Run Relationships in Economics: A Comparison of Different Approaches. Journal of Econometrics, 57, 53-68.

[32] Banerjee, et al. (1993) Panel Data Unit Roots and Cointegration: An Overview. OXford Bulletin of economics and Statistics, 61, 607-629.

https://doi.org/10.1111/1468-0084.61.s1.12

[33] Alam, M.I. and Quazi, R.M. (2003), Determinants of Capital Flight: An Econometric Case Study of Bangladesh. International Review of Applied Economics, 17, 85-103. https://doi.org/10.1080/713673164 


\section{Annexes}

Table A1. Correlation matrix ( $p$-values are in parentheses).

\begin{tabular}{|c|c|c|c|c|c|c|c|c|c|}
\hline & lpibhbt & Lfbcf & llabor & laide & ldep & lcredit & dprim & Inf_pib & IDE \\
\hline lpibhbt & 1 & & & & & & & & \\
\hline \multirow[t]{2}{*}{ Lfbcf } & 0.0509 & 1 & & & & & & & \\
\hline & $(0.3699)$ & & & & & & & & \\
\hline \multirow[t]{2}{*}{ llabor } & -0.5371 & -0.0261 & 1 & & & & & & \\
\hline & $(0.000)$ & $(0.6463)$ & & & & & & & \\
\hline \multirow[t]{2}{*}{ Laide } & -0.7323 & 0.2029 & 0.4302 & 1 & & & & & \\
\hline & $(0.000)$ & $(0.0003)$ & $(0.000)$ & & & & & & \\
\hline \multirow[t]{2}{*}{ Ldep } & -0.4256 & 0.5844 & 0.3107 & 0.5285 & 1 & & & & \\
\hline & $(0.000)$ & $(0.000)$ & $(0.000)$ & $(0.000)$ & & & & & \\
\hline \multirow[t]{2}{*}{ lcredit } & 0.6179 & 0.3151 & -0.3145 & -0.3467 & 0.0555 & 1 & & & \\
\hline & $(0.000)$ & $(0.000)$ & $(0.000)$ & $(0.000)$ & $(0.3282)$ & & & & \\
\hline \multirow[t]{2}{*}{ dprim } & -0.0947 & 0.0935 & 0.0618 & 0.0894 & 0.1231 & -0.0104 & 1 & & \\
\hline & $(0.1015)$ & $(0.1059)$ & $(0.2861)$ & $(0.1222)$ & $(0.033)$ & $(0.858)$ & & & \\
\hline \multirow[t]{2}{*}{ Inf_pib } & 0.0908 & -0.0813 & 0.0125 & -0.0885 & -0.1891 & -0.2226 & -0.1064 & 1 & \\
\hline & $(0.1094)$ & $(0.1519)$ & $(0.8256)$ & $(0.1188)$ & $(0.0008)$ & $(0.0001)$ & $(0.0658)$ & & \\
\hline \multirow[t]{2}{*}{ IDE } & -0.0176 & 0.1898 & 0.0889 & -0.0706 & 0.2365 & 0.0684 & 0.0551 & 0.0913 & 1 \\
\hline & 0.7565 & 0.0008 & 0.1171 & 0.2134 & 0 & 0.228 & 0.3415 & 0.1075 & \\
\hline
\end{tabular}

Source: calcul de l'auteur.

Table A2. Tests of Stationarity.

\begin{tabular}{ccccccc}
\hline & LLC & Hadri & Philpps Perron & IPS & Breitung & Conclusion \\
\hline lpibhbt & $\mathrm{I}(1)$ & $\mathrm{I}(2)$ & $\mathrm{I}(1)$ & $\mathrm{I}(1)$ & $\mathrm{I}(1)$ & $\mathrm{I}(1)$ \\
lfbcf & $\mathrm{I}(1)$ & $\mathrm{I}(1)$ & $\mathrm{I}(1)$ & $\mathrm{I}(1)$ & $\mathrm{I}(1)$ & $\mathrm{I}(1)$ \\
Main d'œuvre & $\mathrm{I}(1)$ & $\mathrm{I}(1)$ & $\mathrm{I}(1)$ & $\mathrm{I}(1)$ & $\mathrm{I}(1)$ & $\mathrm{I}(1)$ \\
laide & $\mathrm{I}(0)$ & $\mathrm{I}(1)$ & $\mathrm{I}(0)$ & $\mathrm{I}(1)$ & $\mathrm{I}(0)$ & $\mathrm{I}(0)$ \\
ldep & $\mathrm{I}(0)$ & $\mathrm{I}(1)$ & $\mathrm{I}(0)$ & $\mathrm{I}(0)$ & $\mathrm{I}(0)$ & $\mathrm{I}(0)$ \\
primaire & $\mathrm{I}(1)$ & $\mathrm{I}(1)$ & $\mathrm{I}(1)$ & $\mathrm{I}(1)$ & $\mathrm{I}(1)$ & $\mathrm{I}(1)$ \\
lcredit & $\mathrm{I}(1)$ & $\mathrm{I}(2)$ & $\mathrm{I}(1)$ & $\mathrm{I}(1)$ & $\mathrm{I}(1)$ & $\mathrm{I}(1)$ \\
louvert & $\mathrm{I}(1)$ & $\mathrm{I}(1)$ & $\mathrm{I}(0)$ & $\mathrm{I}(1)$ & $\mathrm{I}(1)$ & $\mathrm{I}(1)$ \\
IDE & $\mathrm{I}(0)$ & $\mathrm{I}(1)$ & $\mathrm{I}(0)$ & $\mathrm{I}(0)$ & $\mathrm{I}(0)$ & $\mathrm{I}(0)$ \\
Inf_pib & $\mathrm{I}(0)$ & $\mathrm{I}(0)$ & $\mathrm{I}(0)$ & $\mathrm{I}(0)$ & $\mathrm{I}(0)$ & $\mathrm{I}(0)$ \\
\hline
\end{tabular}

Source: author calculations. 
Table A3. VAR model estimation results: Impact of Total Public Spending on growth in Ghana, Nigéria, Sénégal and Togo.

\begin{tabular}{|c|c|c|c|c|}
\hline \multicolumn{5}{|c|}{ Togo } \\
\hline & dlpibhbt & dldept & $\mathrm{dlfbcft}$ & dllabort \\
\hline & coef & coef & coef & coef \\
\hline dlpibhbt-1 & $0.496^{* * *}$ & $0.586^{* * *}$ & $2.209^{* * *}$ & $0.006^{* *}$ \\
\hline dlpibhbt-2 & -0.122 & 0.04 & 0.787 & -0.00004 \\
\hline dldept-1 & $-1.667^{\star * *}$ & $-0.976^{\star * *}$ & $-5.259^{* * *}$ & $-0.012^{\star *}$ \\
\hline dldept-2 & -0.329 & $-0.664^{* * *}$ & -1.607 & -0.001 \\
\hline dlfbcft-1 & $0.254^{\star * *}$ & 0.032 & $-0.572^{\star *}$ & -0.0001 \\
\hline dlfbcft-2 & $0.217^{\star \star *}$ & 0.043 & 0.127 & 0.0004 \\
\hline dllabort-1 & $81.611^{* * *}$ & $38.155^{\star \star \star}$ & $159.242^{* *}$ & $1.403^{* * *}$ \\
\hline dllabort-2 & $-78.209^{* * *}$ & $-35.548^{\star * *}$ & $-190.81^{* *}$ & $-0.409^{*}$ \\
\hline IDE & $-0.002^{*}$ & 0.002 & 0.001 & $0.00004^{*}$ \\
\hline laide & 0.008 & -0.012 & -0.089 & 0.0003 \\
\hline Inf_pib & $0.004^{* * *}$ & $-0.002^{\star *}$ & 0.007 & $-0.0001^{* * *}$ \\
\hline dprim & $-0.009^{* * *}$ & $-0.006^{* * *}$ & -0.006 & $-0.0001^{* *}$ \\
\hline dlcredit & $-0.113^{* *}$ & $-0.118^{\star * *}$ & -0.255 & $-0.004^{* * *}$ \\
\hline _cons & 0.012 & $0.051^{* *}$ & $0.339^{* *}$ & -0.0002 \\
\hline \multicolumn{5}{|c|}{ Sénégal } \\
\hline & dlpibhbt & dldept & dlfbcft & dllabort \\
\hline & coef & coef & coef & coef \\
\hline dlpibhbt-1 & -0.022 & -0.206 & $2.533^{* * *}$ & -0.177 \\
\hline dlpibhbt-2 & 0.226 & 0.122 & $-1.682^{*}$ & 0.1 \\
\hline dldept-1 & $-0.323^{*}$ & -0.031 & 0.201 & -0.102 \\
\hline dldept-2 & -0.221 & $-0.393^{* *}$ & -0.9 & -0.019 \\
\hline dlfbcft-1 & 0.098 & 0.019 & -0.275 & 0.019 \\
\hline dlfbcft-2 & $0.161^{*}$ & 0.046 & 0.018 & $0.089^{* *}$ \\
\hline dllabort-1 & -0.395 & -0.775 & $-3.058^{*}$ & 0.201 \\
\hline dllabort-2 & 0.317 & -0.111 & 1.178 & $0.573^{* *}$ \\
\hline IDE & 0.007 & 0.003 & 0.015 & $0.006^{* * *}$ \\
\hline laide & 0.024 & -0.033 & $-0.213^{* *}$ & -0.004 \\
\hline Inf_pib & $-0.002^{* *}$ & $0.002^{* *}$ & $0.006^{*}$ & 0.0004 \\
\hline dprim & $0.004^{*}$ & 0.003 & 0.005 & ${ }^{* *} 0.003$ \\
\hline dlcredit & -0.051 & $0.126^{* *}$ & -0.236 & 0.023 \\
\hline _cons & -0.053 & 0.054 & $0.409^{*}$ & -0.009 \\
\hline
\end{tabular}




\section{Continued}

\begin{tabular}{|c|c|c|c|c|}
\hline \multicolumn{5}{|c|}{ Ghana } \\
\hline & dlpibhbt & dldept & dlfbcft & dllabort \\
\hline & coef & coef & coef & coef \\
\hline dlpibhbt-1 & 0.205 & 0.031 & 2.214 & 0.032 \\
\hline dlpibhbt-2 & $-0.557^{\star *}$ & 0.672 & 2.863 & -0.026 \\
\hline dldept-1 & $-0.144^{\star}$ & $-0.402^{\star \star}$ & 0.363 & -0.016 \\
\hline dldept-2 & $-0.185^{\star \star}$ & 0.108 & 0.835 & 0.024 \\
\hline dlfbcft-1 & 0.022 & -0.065 & $-0.633^{\star * *}$ & -0.003 \\
\hline dlfbcft-2 & 0.009 & $-0.118^{\star *}$ & $-0.417^{\star}$ & -0.011 \\
\hline dllabort-1 & $1.118^{\star *}$ & $2.224^{* *}$ & $14.275^{\star \star}$ & $0.669^{\star * *}$ \\
\hline dllabort-2 & $-0.982^{\star *}$ & -1.13 & -4.717 & 0.072 \\
\hline IDE & $-0.008^{\star *}$ & $-0.016^{* *}$ & -0.045 & -0.0003 \\
\hline laide & $-0.061^{\star * *}$ & -0.008 & 0.218 & -0.005 \\
\hline Inf_pib & $-0.001^{* * *}$ & -0.001 & -0.004 & $2.00 \mathrm{E}-04$ \\
\hline dprim & $0.002^{*}$ & 0.004 & 0.019 & $0.002^{* *}$ \\
\hline dlcredit & $-0.173^{* * *}$ & -0.021 & -0.531 & $2.10 \mathrm{E}-02$ \\
\hline _cons & $0.233^{* * *}$ & 0.085 & -0.25 & $2.00 \mathrm{E}-03$ \\
\hline \multicolumn{5}{|c|}{ Nigéria } \\
\hline & dlpibhbt & Dldept & $\mathrm{dlfbcft}$ & dllabort \\
\hline & coef & Coef & coef & coef \\
\hline dlpibhbt-1 & -0.042 & -1.387 & -1.896 & $0.028^{* * *}$ \\
\hline dlpibhbt-2 & 0.53 & $3.031^{\star}$ & $8.011^{\star *}$ & -0.007 \\
\hline dldept-1 & -0.106 & $-0.339^{\star}$ & -0.101 & 0.0002 \\
\hline dldept-2 & -0.005 & -0.112 & 0.366 & 0.0001 \\
\hline dlfbcft-1 & 0.057 & 0.149 & 0.09 & $-0.002^{\star * *}$ \\
\hline dlfbcft-2 & -0.106 & $-0.312^{* *}$ & $-0.863^{* * *}$ & 0.001 \\
\hline dllabort-1 & -12.416 & $-131.495^{\star *}$ & $-180.859^{\star}$ & $1.025^{\star * *}$ \\
\hline dllabort-2 & 2.257 & $148.749^{* *}$ & $212.178^{* *}$ & 0.028 \\
\hline IDEt & 0.003 & -0.002 & 0.025 & -0.00004 \\
\hline laidet & -0.002 & 0.105 & -0.025 & $0.001^{*}$ \\
\hline Inf_pibt & $-0.001^{*}$ & -0.0004 & -0.002 & $7.98 \mathrm{E}-06$ \\
\hline dprimt & $-0.007^{* *}$ & $0.012^{* *}$ & 0.015 & $2.10 \mathrm{E}-05$ \\
\hline dlcredit & $-0.112^{* *}$ & 0.151 & -0.138 & $4.00 \mathrm{E}-04$ \\
\hline _cons & 0.011 & 0.061 & -0.132 & $-1.00 \mathrm{E}-04$ \\
\hline
\end{tabular}

Source: author calculations. 
Table A4. VAR model estimation results: Impact of Public Consomption on growth in Ghana, Nigéria, Sénégal and Togo.

\begin{tabular}{|c|c|c|c|c|}
\hline \multicolumn{5}{|c|}{ GHANA } \\
\hline & dlpibhbt & dldepconst & dlfbcft & dllabort \\
\hline & coef & coef & coef & coef \\
\hline dlpibhbt-1 & 0.233 & 7.87 & $2.875^{\star}$ & 0.038 \\
\hline dlpibhbt-2 & $-0.444^{\star}$ & $-33.946^{\star *}$ & 3.431 & -0.024 \\
\hline dldepconst-1 & -0.001 & $-0.601^{* * *}$ & $-0.068^{\star * *}$ & -0.001 \\
\hline dldepconst-2 & 0.002 & -0.32 & -0.043 & 0.002 \\
\hline dlfbcft-1 & 0.01 & 0.638 & $-0.554^{* * *}$ & 0.004 \\
\hline dlfbcft-2 & -0.014 & -0.447 & -0.205 & -0.004 \\
\hline dllabort-1 & $1.308^{\star * *}$ & 10.562 & $10.765^{\star *}$ & $0.604^{* * *}$ \\
\hline dllabort-2 & $-0.829^{\star}$ & 9.32 & -2.525 & 0.171 \\
\hline IDE & $-0.009^{* * *}$ & $-0.540^{\star *}$ & -0.045 & $0.0001^{*}$ \\
\hline laide & $-0.057^{\star * *}$ & $-3.552^{\star *}$ & 0.212 & -0.002 \\
\hline Inf_pib & $-0.001^{\star *}$ & $-0.081^{* *}$ & -0.004 & $-0.0003^{* *}$ \\
\hline dprim & $0.004^{* *}$ & 0.031 & 0.018 & $0.002^{* * *}$ \\
\hline dlcredit & $-0.113^{\star *}$ & $-9.175^{\star * *}$ & 0.09 & $0.031^{* *}$ \\
\hline _cons & 0.213 & $12.721^{\star * *}$ & -0.276 & -0.011 \\
\hline \multicolumn{5}{|c|}{ NIGERIA } \\
\hline & dlpibhbt & dldepconst & dlfbcft & dllabort \\
\hline & coef & coef & coef & coef \\
\hline dlpibhbt-1 & 0.313 & -6.203 & -2.743 & $0.029^{* * *}$ \\
\hline dlpibhbt-2 & -0.458 & 6.596 & $8.428^{* *}$ & -0.001 \\
\hline dldepconst-1 & -0.0002 & $-0.765^{\star * *}$ & -0.012 & $0.0001^{*}$ \\
\hline dldepconst-2 & -0.01 & -0.25 & 0.009 & 0.0001 \\
\hline dlfbcft-1 & 0.055 & $4.404^{* * *}$ & 0.084 & $-0.003^{* * *}$ \\
\hline dlfbcft-2 & -0.039 & 2.911 & $-0.807^{\star *}$ & -0.0002 \\
\hline dllabort-1 & 19.038 & -203.566 & $-217.304^{\star}$ & $0.881^{* *}$ \\
\hline dllabort-2 & -30.037 & 187.118 & $250.556^{*}$ & 0.188 \\
\hline IDE & -0.001 & -0.055 & 0.017 & 0.00003 \\
\hline laide & -0.014 & 0.003 & 0.05 & 0.001 \\
\hline Inf_pib & -0.001 & $-0.027^{\star \star}$ & $-003^{*}$ & $7.00 \mathrm{E}-06$ \\
\hline dprim & $-0.007^{\star \star}$ & $0.229^{\star * \star}$ & 0.017 & $5.00 \mathrm{E}-06$ \\
\hline dlcredit & $-0.107^{\star}$ & $-2.828^{\star *}$ & -0.16 & 0.0004 \\
\hline _cons & 0.03 & 1.043 & -0.037 & -0.001 \\
\hline
\end{tabular}


Continued

\begin{tabular}{|c|c|c|c|c|}
\hline \multicolumn{5}{|c|}{ Sénégal } \\
\hline & dlpibhbt & dldepconst & dlfbcft & dllabort \\
\hline & coef & coef & coef & coef \\
\hline dlpibhbt-1 & 0.462 & 0.791 & $2.311^{\star}$ & $-0.395^{\star \star}$ \\
\hline dlpibhbt-2 & -0.326 & -0.533 & $-1.961^{\star}$ & 0.164 \\
\hline dldepconst-1 & $0.105^{\star *}$ & $-1^{* * *}$ & -0.036 & -0.03 \\
\hline dldepconst-2 & 0.005 & -0.009 & 0.09 & 0.003 \\
\hline dlfbcft-1 & $0.139^{* *}$ & $-0.968^{*}$ & -0.31 & -0.029 \\
\hline dlfbcft-2 & $0.108^{*}$ & $-1.102^{\star *}$ & -0.222 & $0.051^{*}$ \\
\hline dllabort-1 & -0.239 & -2.525 & -3.023 & 0.194 \\
\hline dllabort-2 & 0.362 & -0.421 & 0.301 & 0.413 \\
\hline IDE & 0.001 & $0.07^{*}$ & 0.008 & $0.007^{\star * *}$ \\
\hline laide & $0.061^{\star *}$ & $-0.694^{* *}$ & $-0.260^{\star *}$ & -0.019 \\
\hline Inf_pib & $-0.004^{* * *}$ & 0.011 & $0.009^{* *}$ & $0.001^{\star}$ \\
\hline dprim & $0.004^{*}$ & -0.03 & -0.001 & $2.00 \mathrm{E}-03$ \\
\hline dlcredit & $-0.154^{* *}$ & 0.858 & -0.044 & $0.066^{*}$ \\
\hline _cons & $-0.114^{*}$ & $1.344^{* *}$ & $0.514^{\star *}$ & 0.021 \\
\hline \multicolumn{5}{|c|}{ TOGO } \\
\hline & dlpibhbt & dldepconst & dlfbcft & dllabort \\
\hline & coef & coef & coef & coef \\
\hline dlpibhbt-1 & 0.179 & -8.876 & 0.711 & $0.004^{* *}$ \\
\hline dlpibhbt-2 & $-0.177^{\star}$ & 5.67 & 0.327 & -0.001 \\
\hline dldepconst-1 & $0.019^{\star * *}$ & $-0.942^{\star * *}$ & 0.021 & $4.00 \mathrm{E}-05$ \\
\hline dldepconst-2 & $0.007^{\star *}$ & $-0.697^{\star * *}$ & 0.011 & $-5.00 \mathrm{E}-05$ \\
\hline dlfbcft-1 & $0.294^{* * *}$ & -0.184 & -0.408 & $-3.00 \mathrm{E}-04$ \\
\hline dlfbcft-2 & $0.105^{\star \star}$ & -0.731 & -0.05 & $-5.00 \mathrm{E}-04$ \\
\hline dllabort-1 & $49.447^{\star * *}$ & $-1702.936^{\star * \star}$ & 15.177 & $1.134^{\star * *}$ \\
\hline dllabort-2 & $-52.224^{\star * \star}$ & $1713.633^{* * *}$ & -57.584 & -0.203 \\
\hline IDE & $-0.005^{\star * *}$ & 0.005 & -0.005 & $2.00 \mathrm{E}-05$ \\
\hline laide & 0.006 & -0.687 & -0.056 & $2.00 \mathrm{E}-04$ \\
\hline Inf_pib & $0.006^{* * *}$ & 0.068 & $0.011^{*}$ & $-0.0001^{\star * *}$ \\
\hline dprim & $-0.003^{\star *}$ & 0.108 & 0.013 & $-4.00 \mathrm{E}-05$ \\
\hline dlcredit & -0.028 & $5.488^{\star * *}$ & 0.106 & $-0.003^{\star * *}$ \\
\hline _cons & 0.005 & 0.283 & 0.205 & $-1.00 \mathrm{E}-04$ \\
\hline
\end{tabular}

Source: author estimations. 
Table A5. VAR model estimation results: Impact Public Investment (fbcfpub) on growth in Ghana, Nigéria, Sénégal and Togo.

\begin{tabular}{|c|c|c|c|c|}
\hline \multicolumn{5}{|c|}{ BENIN } \\
\hline & dlpibhbt & dldepconst & dlfbcfpubt & dllabort \\
\hline & coef & coef & coef & coef \\
\hline dlpibhbt-1 & -0.003 & -2.769 & -0.741 & 0.169 \\
\hline dlpibhbt-2 & 0.216 & $26.860^{\star *}$ & $-1.852^{*}$ & 0.204 \\
\hline dldepconst-1 & $4.85 \mathrm{E}-04$ & -0.459 & -0.073 & $-1.00 \mathrm{E}-02$ \\
\hline dldepconst-2 & $-3.07 \mathrm{E}-04$ & 0.009 & -0.105 & $-0.048^{\star *}$ \\
\hline dlfbcfpubt-1 & 0.011 & 0.564 & -0.258 & $-0.141^{\star *}$ \\
\hline dlfbcfpubt-2 & $0.024^{*}$ & -0.572 & -0.059 & $-1.40 \mathrm{E}-02$ \\
\hline dllabort-1 & -0.3 & -4.148 & 2.497 & $1.243^{* *}$ \\
\hline dllabort-2 & $-0.300^{* * *}$ & 1.688 & $-1.22^{\star *}$ & -0.026 \\
\hline IDE & 0.001 & 0.067 & $-0.008^{*}$ & $-1.00 \mathrm{E}-03$ \\
\hline laide & 0.011 & $2.02^{* *}$ & 0.051 & $0.054^{* *}$ \\
\hline Inf_pib & $-0.001^{\star *}$ & 0.009 & $-0.006^{* * *}$ & -0.00007 \\
\hline dprim & $-9.05 \mathrm{E}-05$ & 0.027 & 0.004 & $1.00 \mathrm{E}-03$ \\
\hline dlouvert & $0.056^{* * *}$ & 0.901 & 0.097 & -0.005 \\
\hline _cons & -0.064 & -4.532 & 1.964 & $0.124^{*}$ \\
\hline \multicolumn{5}{|c|}{ Guinée Conakry } \\
\hline & dlpibhbt & dldepconst & dlfbcfpubt & dllabort \\
\hline & coef & coef & coef & coef \\
\hline dlpibhbt-1 & -0.258 & $10.247^{* * *}$ & $-2.093^{\star *}$ & -0.002 \\
\hline dlpibhbt-2 & -0.054 & 3.319 & -0.817 & 0.007 \\
\hline dldepconst-1 & $7.00 \mathrm{E}-03$ & -0.28 & 0.094 & $-3.83 \mathrm{E}-04$ \\
\hline dldepconst-2 & $-0.033^{\star *}$ & 0.149 & 0.001 & $-3.46 \mathrm{E}-04$ \\
\hline dlfbcfpubt-1 & -0.037 & -1.167 & $1.266^{* * *}$ & $-1.00 \mathrm{E}-03$ \\
\hline dlfbcfpubt-2 & 0.058 & 0.292 & -0.038 & $-1.00 \mathrm{E}-03$ \\
\hline dllabort-1 & -5.699 & 2.597 & 25.971 & $1.155^{* * *}$ \\
\hline dllabort-2 & 0.457 & 14.022 & -16.999 & -0.131 \\
\hline IDE & -0.001 & 0.019 & -0.001 & $7.93 \mathrm{E}-06$ \\
\hline laide & -0.026 & $1.676^{* *}$ & -0.244 & -0.001 \\
\hline Inf_pib & 0.003 & -0.022 & $0.013^{* *}$ & $5.21 \mathrm{E}-05$ \\
\hline dprim & $-3.00 \mathrm{E}-03$ & 0.027 & $0.036^{* *}$ & $-5.06 \mathrm{E}-05$ \\
\hline dlouvert & $-0.233^{\star *}$ & -0.155 & $-1.64 \mathrm{E}-01$ & $1.00 \mathrm{E}-03$ \\
\hline _cons & 0.075 & -3.034 & 0.096 & 0.007 \\
\hline
\end{tabular}


Continued

\begin{tabular}{|c|c|c|c|c|}
\hline \multicolumn{5}{|c|}{ Niger } \\
\hline & dlpibhbt & dldepconst & dlfbcfpubt & dllabort \\
\hline & coef & coef & coef & coef \\
\hline dlpibhbt-1 & -0.258 & $10.247^{\star * *}$ & $-2.093^{\star * *}$ & -0.002 \\
\hline dlpibhbt-2 & -0.054 & 3.319 & -0.817 & 0.008 \\
\hline dldepconst-1 & 0.007 & -0.28 & 0.094 & -0.0003 \\
\hline dldepconst-2 & $-0.033^{\star *}$ & 0.149 & 0.001 & -0.0003 \\
\hline dlfbcfpubt-1 & -0.038 & -1.167 & 1.266 & -0.001 \\
\hline dlfbcfpubt-2 & 0.057 & 0.292 & -0.038 & -0.001 \\
\hline dllabort-1 & -5.699 & 2.597 & 25.971 & $1.155^{\star * *}$ \\
\hline dllabort-2 & 0.457 & 14.023 & -16.999 & -0.131 \\
\hline IDE & -0.001 & 0.019 & -0.001 & $7.93 \mathrm{E}-06$ \\
\hline laide & -0.026 & $1.676^{* * *}$ & -0.244 & 0.001 \\
\hline Inf_pib & 0.003 & -0.022 & 0.007 & $-5.21 \mathrm{E}-05$ \\
\hline dprim & -0.003 & -0.016 & $0.036^{\star * *}$ & $-5.06 \mathrm{E}-05$ \\
\hline dlouvert & -0.233 & -0.155 & -0.164 & 0.001 \\
\hline _cons & 0.075 & -3.034 & 0.096 & 0.007 \\
\hline \multicolumn{5}{|c|}{ Senegal } \\
\hline & dlpibhbt & dldepconst & dlfbcfconst & dllabort \\
\hline & coef & coef & coef & coef \\
\hline dlpibhbt-1 & -0.291 & 3.172 & 0.24 & $-0.332^{* * *}$ \\
\hline dlpibhbt-2 & -0.188 & -3.783 & -205 & -0.139 \\
\hline dldepconst-1 & 0.013 & $-0.479^{*}$ & -0.052 & -0.015 \\
\hline dldepconst-2 & -0.004 & $-0.497^{\star *}$ & -0.012 & $-0.028^{\star *}$ \\
\hline dlfbcfconst-1 & -0.001 & 1.243 & 0.271 & $0.335^{\star * *}$ \\
\hline dlfbcfconst-2 & 0.208 & $2.930^{*}$ & 0.226 & 0.104 \\
\hline dllabort-1 & -0.464 & $-10.789^{\star *}$ & -0.673 & 0.023 \\
\hline dllabort-2 & -0.268 & $7.334^{*}$ & 0.714 & 0.289 \\
\hline IDE & 0.002 & 0.045 & $0.024^{* * *}$ & $2.00 \mathrm{E}-03$ \\
\hline laide & 0.032 & -0.151 & -0.051 & 0.271 \\
\hline Inf_pib & $-0.002^{\star}$ & -0.008 & -0.001 & $0.001^{*}$ \\
\hline dprim & 0.001 & 0.014 & -0.003 & $0.003^{* * *}$ \\
\hline dlouvert & 0.023 & -0.998 & -0.066 & $-0.066^{*}$ \\
\hline _cons & 0.381 & -6.326 & 0.063 & $-0.754^{* * *}$ \\
\hline
\end{tabular}




\section{Continued}

\begin{tabular}{ccccc}
\hline & \multicolumn{3}{c}{ TOGO } & \\
\hline & dlpibhbt & dldepconst & dlfbcfpubt & dllabort \\
\hline coef & coef & coef & coef \\
\hline dlpibhbt-1 & $0.441^{* *}$ & -4.156 & -1.426 & -0.002 \\
dlpibhbt-2 & 0.077 & -3.717 & $2.485^{*}$ & 0.002 \\
dldepconst-1 & $0.014^{* * *}$ & $-0.730^{* * *}$ & 0.049 & $-3.00 \mathrm{E}-05$ \\
dldepconst-2 & 0.006 & $-0.679^{* * *}$ & 0.051 & $-3.72 \mathrm{E}-05$ \\
dlfbcfpubt-1 & 0.022 & 0.568 & $0.403^{*}$ & $-3.90 \mathrm{E}-04$ \\
dlfbcfpubt-2 & -0.025 & -0.469 & $-0.442^{* *}$ & $-2.38 \mathrm{E}-05$ \\
dllabort-1 & $52.311^{* *}$ & 1086.908 & $-344.305^{*}$ & $0.754^{* * *}$ \\
dllabort-2 & $-62.021^{* * *}$ & -1088.406 & 234.555 & 0.194 \\
IDE & $-0.005^{*}$ & $0.210^{* *}$ & -0.025 & $1.33 \mathrm{E}-05$ \\
laide & -0.008 & 0.346 & $0.412^{* *}$ & $2.88 \mathrm{E}-04$ \\
Inf_pib & $0.005^{* * *}$ & -0.041 & 0.014 & $-2.97 \mathrm{E}-06$ \\
dprim & -0.003 & 0.001 & $0.059^{* *}$ & $4.66 \mathrm{E}-05$ \\
dlouvert & 0.147 & -3.442 & -0.041 & 0.001 \\
_cons & 0.063 & -0.989 & 0.673 & -0.0003 \\
\hline
\end{tabular}

Source: author estimations.

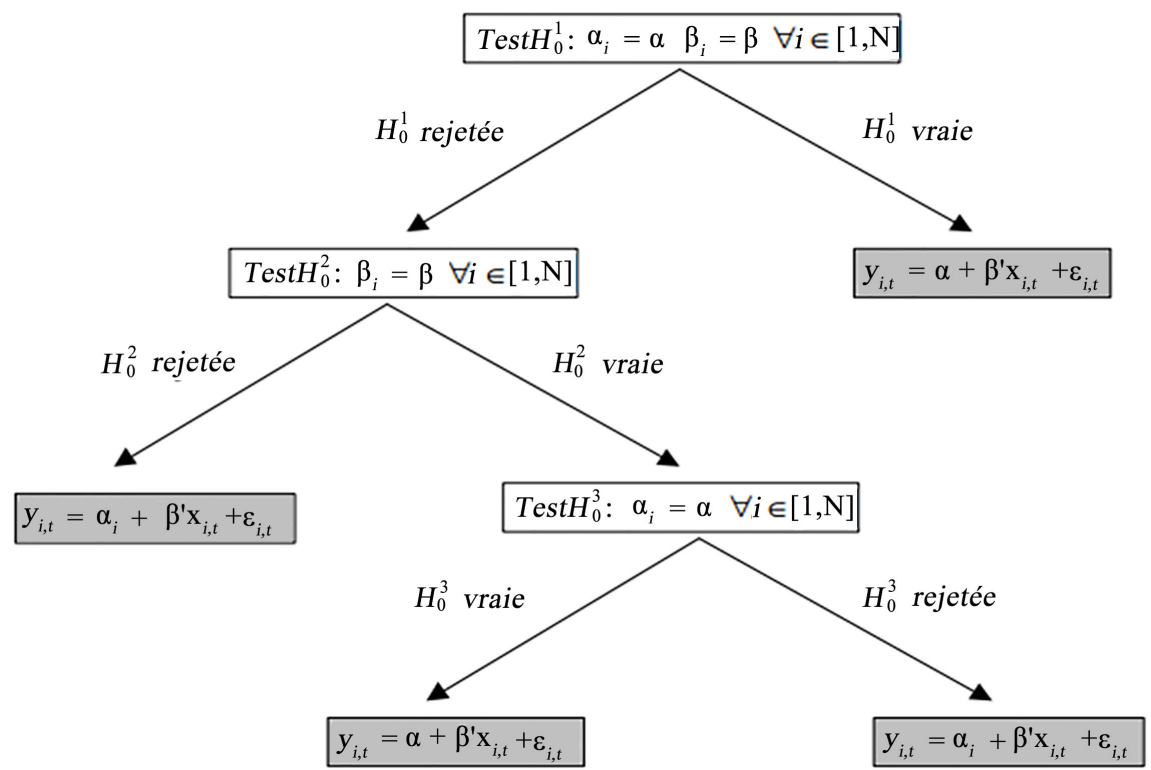

Figure A1. HSIAO specification test. $H_{0}^{i}$ rejetée $=H_{0}^{i}$ rejected $H_{0}^{i}$ vraie $=H_{0}^{i}$ accepted. Source: C. Hurlin (2006), "L'économétrie des données de panels-modèles linéaires simples". 